\title{
Illness as Depicted in the Illustrated Legends of Kokawa Temple
}

YАMAмото Satomi

Translated by Jeffrey KNOTT

\section{Introduction}

Leafing through Buddhist scriptures, one finds not infrequent reference to the view that illness, ultimately, was merely the working out of karmic justice-the result of evil acts perpetrated over the course of one's present-or past-life existence. For example, in the "Parables" chapter (Hiyu-hon 譬喻品) of the Sutra of the Lotus Flower of the Wonderful Law (“The Lotus Sutra”, Myōbō renge kyo 妙法蓮華経), one encounters the following explanation regarding the karmic relationship between illness and the sin of disrespecting sacred texts:

The sins to be incurred for the act of slandering this scripture are as follows. Even should one successfully attain to humanity, he will be short in stature, prone to seizures, limp-legged, blind, deaf-mute, and hunchbacked. Should he have aught to speak, he will not be given ear by others. His breath will ever stink. He will be possessed by demons. He will be poor and mean of status, and made servant to others' will. He will suffer many illnesses, grow wasted and wan, and find nothing whereupon to rely. Should he do others a kindness, others will not remember it. Should ever he gain possession of something, he will soon find it lost again. Even should he learn the craft of healing, and cure some disease according to the art, he will only bring on further diseases besides, if not indeed cause death. And should he fall prey to disease himself, none other will there be to save him. Indeed, even should he take an efficacious drug, it will only multiply his pains. ${ }^{1}$

Here it is warned that anyone who has slandered the Lotus Sutra, even if he does manage to escape rebirth in Hell or the world of Hungry Ghosts (gaki 餓鬼), and somehow returns to life as a human being once more, will find himself short of stature, prone to seizures, limp-legged, blind or deaf-mute, and hunchbacked.

This kind of thinking, with its tendency to inspire discrimination against the ill and the handicapped, may be quite alien to the moral and medical understanding of the present day. In premodern Japan, however, attitudes towards illness were

\footnotetext{
${ }^{1}$ Taishō shinshū daižōkyō 大正新脩大蔵経, vol. 9, p. 15c.
} 
predicated to a greater or lesser extent on precisely such religious teachings. Prayer rituals for recovery from sickness, votive scripture-copying, Buddhist statute-casting for the sake of lengthened life-all such activities were carried out in order to dispel the evil karma that caused illness, or to build up deposits of the good.

Inscribed, for example, in the diagrammatic painting Transformation Scenes from the Lotus Sutra (Myōhō renge kyō hensōzu 妙法蓮華経変相図, Southern Song period, $12^{\text {th }}$ c., Seikadō Library 静嘉堂文庫 Archives), we find representations of people suffering from dwarfism and blindness that match the sutra passage quoted above. It is thought that the imagery of illness as a retribution for bad deeds was developed through such religious paintings, and through them also brought eventually to Heian-period Japan. Thus we find in the illustrated scroll Yamai no $s o ̄ s h i$ 病草子 (“Diseases and Deformities")—a late-Heian work likely produced in the orbit of Retired Emperor Go-Shirakawa 後白河上皇一not only common everyday ailments like stomach pains and toothaches, but also conditions like dwarfism and hunchbackedness, in a sign of the influence that such religious paintings could have.

Furthermore, episodes of illness and the recovery therefrom are featured frequently in the illustrated scrolls of temple and shrine legends that Medieval Japan produced in such numbers - as signs either of one's personal sin, or as the most persuasive evidence of a deity's special favor. In this paper I investigate an early example of this medieval genre, the Illustrated Legends of Kokawa Temple (Kokawa-dera engi emaki 粉河寺縁起絵巻, Kamakura-period, $13^{\text {th }}$ c., Kokawa-dera Temple Archives). Looking in particular at the way this work depicts illness, I consider the relationship of its imagery to Buddhist concepts of karmic sin, and to ideas

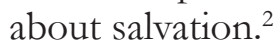

\section{Retired Emperor Go-Shirakawa's Devotion to Kokawa Temple}

The Illustrated Legends of Kokawa Temple has come down to us in the collections of Kokawa Temple itself (Kinokawa City 紀の川, Wakayama Prefecture), a Buddhist temple located in foothills of the Izumi 和泉 mountain range that overlook the Kinokawa 紀の川 river to its south. From the time of its founding, probably as early as the eighth century, the temple's principal image, a statue of Senju (“Thousand-armed") Kannon 千手観音, has been the object of particular religious devotion. And especially after the $11^{\text {th }}$ century, with its vogue in aristocratic circles for religious pilgrimages to destinations on the edge of the central Kinai, like Mt. Kōya 高野山 and Kumano 熊野, we begin to find scattered references of visits to Kokawa Temple in contemporary documents as well.

\footnotetext{
${ }^{2}$ This paper is based on my Japanese article, "Kokawa-dera engi emaki to kyōsetsu: egakareta zaigō, yamai, kyūsai”「「粉河寺縁起絵巻」と経説：描かれた罪業、病、救済, in vol. 8 of Seikatsu to bunka no rekishigaku: Shizen saigai to shippei 生活と文化の歴史学：自然災害と疾病. Eds. Yasuda Masahiko 安田政彦 et al. Tokyo: Chikurinsha, 2017.
} 
In the Pillow Book (Makura no sōshi 枕草子) of Sei Shōnagon 清少納言, we find the following list: “When it comes to temples: Tsubosaka 壳阪, Kasagi 笠置, Hōrin 法輪. Ryōzen 霊山, as the dwelling of Śākyamuni, is said to be particularly moving. Ishiyama 石山. Kokawa 粉河. Shiga 志賀.” The grouping in which Kokawa here finds itself is one of temples on the periphery of the Kinai region: Tsubosaka-dera, Kasagi-dera, Hōrin-ji, Ryōzen-ji, Ishiyama-dera, Shiga-dera, all of them located at some distance from the capital, in the provinces of Yamato, Ōmi, or Kii-though even among these Kokawa Temple is particularly far. To Sei Shōnagon, it no doubt represented an aspirational list, spiritual places of whose names she perhaps had some rumor, but to which she had little hope of making a visit in person.

When considering the late-Heian rise in religious devotion to Kokawa Temple, one figure stands out for being particularly assiduous in its promotion: Retired Emperor Go-Shirakawa (1127-92), the same who during the era of Cloistered Government oversaw the production of so many illustrated scrolls. The beginnings of his devotion to Senju Kannon lay as far back as the first year of the Kyūan 久安 era (1145), when upon the loss of his mother Taikenmon'in 待賢門院 at the age of 19, he received from a monk of Onjō-ji 園城寺 Temple (Miidera 三井寺) a painted image depicting Senju Kannon and the Twenty-Eight Attendants. ${ }^{3}$ As he grew, becoming first emperor, then retired emperor, in the course of his many religious endeavors this devotion of Go-Shirakawa's to Senju Kannon would come to leave lasting traces on his environment - most prominently with the foundation, in the Twelfth Month of Chōkan 長寛 2 (1164), of the temple Renge'o-in 蓮華王院, which enshrined a full thousand-body ensemble of Senju Kannon statues. There is also record of his foundation in Angen 安元 2 (1179) of a small-sized Senju [Kannon] Hall in the hills to the southeast of his Hōjüji 法住寺 Palace, using building materials left-over from the construction of Kokawa Temple's own principal image. ${ }^{4}$ In light of such a history, the circle around the Retired Emperor, a man singularly famous for his love of illustrated scrolls, seems eminently possible as background for the production of the Illustrated Legends of Kokawa Temple. Regarding the particular manuscript copy in question here, however, the most plausible characterization yet put forth sees it as something like a replica, or perhaps an intial secondary copy, of the original scroll produced in Go-Shirakawa's orbit, given features like the roughness visible in its lines, or the format that at several points has both narrative text and illustration on the same sheet of paper, in parts even overlapping. Its date of production would probably be set around the beginning of the $13^{\text {th }}$ century.

\footnotetext{
${ }^{3}$ See the passage "Honzon yurai" 本尊由来 [Origins of the Principal Image] in the text Tenpo rinshōo 転法輪鈔 under the year Bunji 文治 2 (1186).

${ }^{4}$ See Section 21 of the Japanese-language Legends of Kokawa Temple text, under the passage “Go-Shirakawa-hōō go-gan Senju-dō chūzon in’en” 後白河法皇御願千手堂中尊因縁 [Origins of the Central Image in the Senju Hall Built by Cloistered Emperor Go-Shirakawa], in Shoji engi shū 諸寺縁起集. Kunaichō Shoryōbu, 1970.
} 
Yet though both the narrative text and illustrations in this scroll do seem to make reference to previous temple and shrine legend texts, for example the Legends of the Construction of the Great Stupa at Kokawa Temple (Kokawa-dera dai-sotoba konryu engi 粉河寺大率塔婆建立縁起)—with a colophon dated to the seventeenth day of the Second Month of Tengi 天喜 $2(1054)^{5}$ —at the same time some of what they contain is in fact unique, and found in no other temple and shrine legend texts. The scroll consists of five sections in total, which divide into a two-episode structure: the first an origin story about how Kokawa Temple was founded by the prayers of a certain hunter (Sections 1 and 2), and the second a miracle story about how a certain rich man's daughter recovered from her illness by the merits of the temple's principal image, the statue of Senju Kannon (Sections 3-5).

Because of the text's exposure to fire at some point in its transmission, in particular Section 1, at the head of the scroll, has suffered heavy damage. The part that concerns this paper's investigation, however, is the story of the rich man's daughter's recovery from illness, located in the second episode and in portions of the scroll untouched by fire. While paying due attention, then, to the physical state of the manuscript, it is possible to proceed with my study as planned.

In the investigation below, with a focus on this tale of recovery in the text's second episode, I attempt to interpret the iconography which the scroll uses for its depictions of sin and salvation. When quotations from the manuscript happen to include instances of textual damage, I supply the missing words in brackets [ ] from another text surviving in Kokawa Temple, the work Legends of Kokawa Temple in Kï Province (Kishü Kokawa-dera engi 紀州粉河寺縁起), which bears a copy-date of Genroku 元禄 16 (1703). 6

\section{The Illness of the Rich Man's Daughter and the Legend of King Ajase}

In the scroll's first episode (Sections 1-2), there is a detailed depiction of a scene showing a hunter and his family eating animal flesh. As previous research has repeatedly stressed, the significance of motifs like this meat-eating, or the deerskin visibly depicted at the courtyard's edge, is to emphasize that the lifestyle of the hunter's household violates fusessho-kai 不殺生戒一the Buddhist precept against taking life.

This is one the Five Precepts (gokai 五戒) in Buddhism that not only those who have taken vows, but all laypeople must obey: no taking life (fusesshö-kai 不殺生戒), no stealing (fuchütō-kai 不偷盗戒), no sexual incontinence (fujäin-kai 不邪淫戒), no lying (fumōgo-kai 不妄語戒), and no drinking (fuonju-kai 不飲酒戒). The bad karma produced by breaking one of these can lead to rebirth in Hell or the evil realm of Hungry Ghosts. Because the narrative text for Section 1 is missing, there is no way of knowing if it made mention of either the meat-eating or the

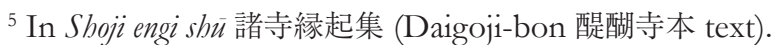

${ }^{6}$ In vol. 5 of Nihon emakimono zenshū 日本絵巻物全集. Tokyo: Kadokawa Shoten, 1962.
} 


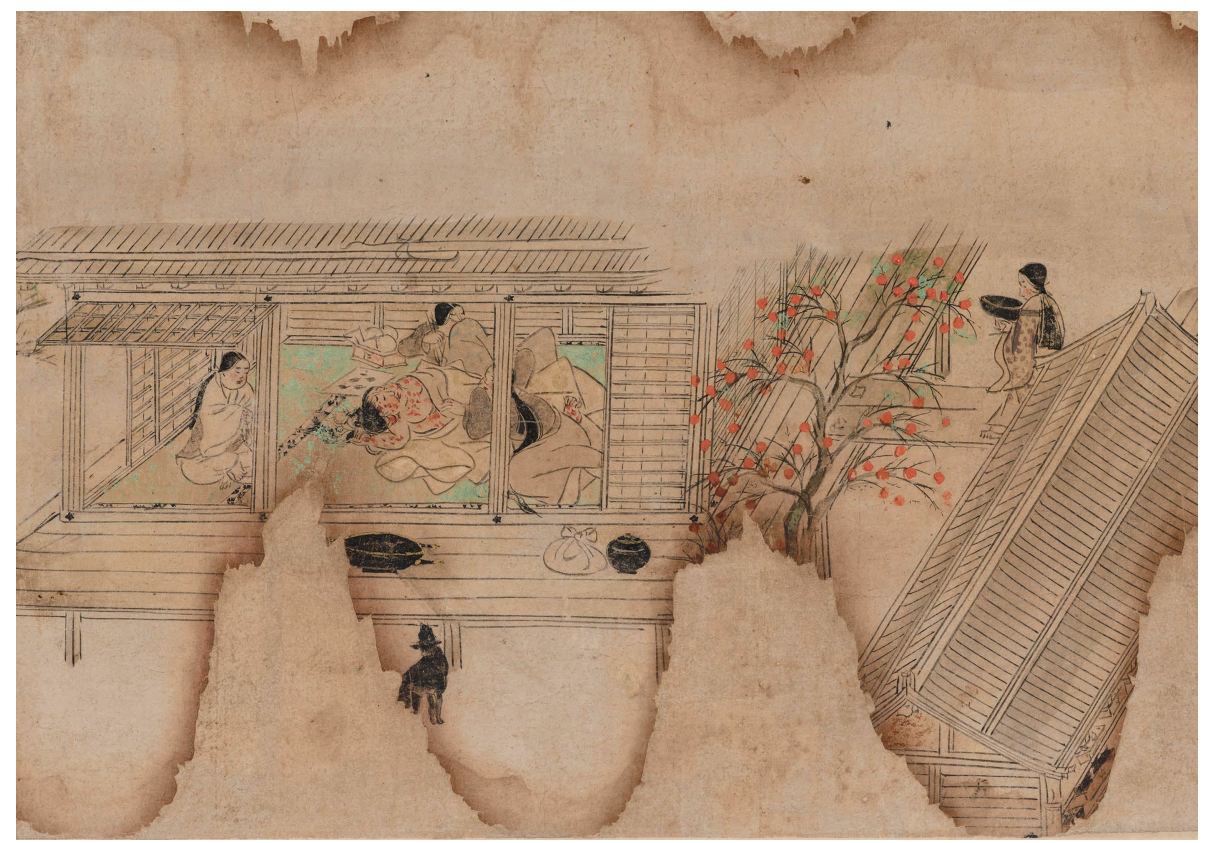

Figure 1. The rich man's daughter stricken with illness. Illustrated Legends of Kokawa Temple, Section 3. Permission of Kokawa Temple.

deerskin, but considering the case of the scroll's second episode as discussed below, it is highly possible that such motifs connected to an evil karmic fate were expressed only in the illustrations. By adding details like these scenes of meat-eating or deerskins into the illustrated portion of the scroll, the moralistic structure of the legend-how through the merits of Kannon those living with the burden of bad karma came to wisdom, and how they were led at last to the good deed of founding the temple-is communicated visually.

The central theme of the scroll's second episode (Sections 3-5) is the illness of the daughter of a rich man living in the Sasara 讃良 District of Kawachi 河内 Province. This illness is characterized by the narrative text accompanying Section 3 in the following way: "Her body's [insides swelled] like a ripe persimmon, and as her [bodily fluid leak] ed the stench was extraordinary."

In the illustrated portion of the same Section 3, the body of the bed-ridden daughter is swollen, leaving the skin ruptured in several places, with red pus and blood oozing from the wounds. (Figure 1). Her face twisted in pain, her chest, arms, and legs exposed, her hair in disarray, her appearance is thoroughly indecorous. Even the woman servants tasked with caring for her cover their noses with their sleeves and turn their faces away, a pose that conveys visually the unbearable stench pervading the space around the daughter.

That these symptoms exhibited by the daughter seem to be influenced by images of leprosy (Hansen's disease) — a disease once feared to be incurable-has 
been pointed out by many scholars in the past. Yet it is also worth noting, I would like to add, that symptoms like a foul-smelling body, or one covered with scabs, also align with diseases that many Buddhist scriptural texts see as punishments for sin. To look again at the Lotus Sutra, in the chapter "Exhortations of the Bodhisattva Fugen” (Fugen bosatsu kanbotsu hon 普賢菩薩勧発品) we find the following passage:

(Others ridiculing those who copy out the Lotus Sutra) will, for life upon life, have gaps in their fangs and teeth, lips that are ugly, a flattened nose, arms and legs that twist and bend, and eyes that squint. Their bodies will stink and be unclean, with bleeding from the putrefaction of their awful scabs. Their bellies swollen with water, their breath short, many indeed will be the awful illnesses that assail them. ${ }^{7}$

It is explained that those who ridicule the act of copying out the Lotus Sutra will suffer from various kinds of illness as recompense. The sentence here underlined lists symptoms reminiscent of those experienced by the rich man's daughter as they appear in both narrative and illustrations to Section 3 of the Illustrated Legends of Kokawa Temple: in particular the putrefaction, severe scabbing, and bloody pus.

This understanding of scabs (kasa瘡) and pus (umi 膿) that appear on the surface of the body as punishments for sin is delineated with particular clarity in the legend of King Ajase 阿闍世王, who killed his father-king and usurped his kingdom. Included in many Buddhist writings and Buddhist scriptural texts, it is a legend widely known even in Japan, but the version found in the "Upright Conduct” chapter (Bongyō hon 梵行品) of the sutra Daibatsu nehan kyō 大般涅槃経 is particularly detailed in its recounting of the process by which King Ajase came to repent of his actions, and at length aspired to enlightenment. It is a narrative that contains the following points of interest on the topic of illness.

Born as a prince in Ōshajō 王舎城, the capital of the country of Magada 摩訶陀, Ajase was a man of superlatively evil character, combining violence, slander, greed, wrath, and ignorance all in a single person. Preoccupied always only with the present and unable to look ahead to the future, so obsessed was he with worldly desires, that he killed his own king and father and usurped control of the country.

Immediately afterwards, however, he began burning up with a feeling of shame, developing scabs all over his body and suffering from a stench so bad it was difficult to approach him. At first, six ministers came to him-the jaken rokushin 邪見六臣 (“six minsters of crooked mind")—and tried to soothe King Ajase by arguing from non-Buddhist principles that in fact he had not incurred any sin. Yet in both mind and body he remained unhealed.

Next, there appeared before him a doctor who followed the Buddhist path named Giba 者婆, who instead argued that it was in fact his feeling of shame that

\footnotetext{
${ }^{7}$ Taishō shinshü dairōkeyō 大正新脩大蔵経, vol. 9, p. 62a.
} 
would lead to his salvation. King Ajase, following Giba's advice, went to visit Sākyamuni. With King Ajase before him, then, Sākyamuni entered a meditative state called gatsuai zanmai 月愛三昧 ("the samädbi of moon-radiant love"), whereupon the King was enfolded within a great light. Immediately all the scabs on his body were healed, and he conceived a desire to achieve enlightenment himself.

What I want to note here is how on the road to his awakening, King Ajase had developed scabs all over his body, and had fallen seriously ill at least twice. The first occasion was when the King, tortured by shame ever since the death of his father, and suffering scabs all over his body, was being attended in this sickness by the Lady Idaike 韋提希夫人, his mother. As the scene that follows makes clear, however, this in fact only caused his symptoms to worsen:

The fact of having killed his father produced in him a burning regret, and stripping himself of his finery he no longer made recourse to music and dance. (1) The burn of regret in his heart produced scabs all over his body. Because these scabs reeked with pollution, it was impossible to approach him. As a result King Ajase said to himself in his heart: "Now indeed, however splendid the rewards granted my person heretofore, that day is no longer distant when the rewards of Hell shall grow nigh at last." Subsequently his mother, Idaike by name, had every species of healing ointment applied to him, yet his scabs grew only all the greater, showing no sign of receding or falling away. The king then said to his mother: (2) "Scabs of this nature come not from the body's four elements, but rather from the heart.".

The first underlined passage makes it clear that the reason scabs had broken out on his skin was the heat caused by his feeling of regret. Because moreover such scabbing was only recompense for the sin he had himself committed, King Ajase says that his descent into Hell cannot be too far off, thus admitting how the thought of such a descent into Hell fills him with fear. In the second underlined passage, in the lower half of the paragraph, King Ajase explains to his mother that the reason for the scabbing does not lie with the four great elements - the earth, water, fire, and wind of which bodies are made. It comes rather from his own heart. In other words, as this passage shows, the scabs appearing on King Ajase's body are only the reflection of his own guilty feeling and repentance, and the sign as well of a possible fall into Hell awaiting him not too distantly.

The second occasion is the scene below, where out of thin air he hears the voice of the very king and father he himself had killed.

“It is I, thy father, Himbashara 頻婆娑羅. Be thou now prompt in obedience to the words of the old woman. Heed not the speech of thy six ministers of crooked mind." But when the king had heard this, in agony he fainted and fell to the ground, the scabs on his body growing now even more severe, their reeking pollution twice what it had been. A chilling ointment was applied to treat

${ }^{8}$ Taishō shinshü dairōkyō 大正新脩大蔵経, vol. 12, p. 7a. 
them, but the scabs instead grew hot and their poison burned, only ever increasing with no sign at all they might disappear. ${ }^{9}$

Here the father's voice advises King Ajase not to heed the six ministers whose thoughts are crooked, but instead to follow the advice of Giba, trying thereby to lead to religious awakening the very son who had murdered him. When King Ajase hears such merciful words from his father, however, in the agony of his regret he falls to the ground unconscious, the scabs all over his body growing even worse than before, the stench and the filth twice as bad.

In both of the scenes here examined, King Ajase's experience of his parents' mercy merely sharpened his awareness of the great and irreparable sin he had committed, only deepening his feelings of shame and worsening the seriousness of his symptoms.

In Buddhism, patricide was one of the Five Cardinal Sins (gogyakurai五逆罪): killing one's father (seppu 殺父), killing one's mother (setsumo 殺母), killing an arhat (setsuarakan 殺阿羅漢), causing disunity among monks (bawagōsōo 破和合僧), and wounding the body of a Buddha. (shutsubusshinketsu 出仏身血). Commission of one of these was as serious an offense as violating one of the Five Precepts discussed above. The scabbing and the stench had been engraved into King Ajase's body, quite literally, as a "sign of sin." Yet even as the king suffered in his illness, he came additionally to be tortured by the fear of damnation in Hell.

When we look again now at Section 3 of the Illustrated Legends of Kokawa Temple with such religious teachings in mind, it is easy to imagine how contemporary viewers might well have read into the illness of the rich man's daughter the sign of some karmic sin. Yet what indeed was this sin that the daughter had to take upon herself thus? On this point there is no answer given in the scroll's narrative text. Below, therefore, I continue in my attempts to analyze the scroll's pictorial content.

\section{The Sin of Wealth Accumulation}

At the beginning of the text's second episode, spread across Sections 3 and 4 of the scroll, the prosperous state of the rich man's household is shown through the depiction of a number of valuable objects (Figure 2). Though each section of the scroll has its accompanying narrative text, there is nowhere in them any concrete discussion of the rich man's wealth, making this plethora of valuables a feature present only in the illustrations.

In the illustrated portion of Section 3, we see being brought in, from outside the rich man's gate to the inner courtyard of his mansion, bundles of tanned pelts, birdcages, boxes containing fish, fruits, and pots (of sake?), trunks filled with the delicacies of sea and mountain, quails skewered on branches, and many other items besides. In the courtyard there is a stable, and a space for storing

\footnotetext{
${ }^{9}$ Taishō shinshū dairōkeyō 大正新脩大蔵経, vol. 12, p. 723b.
} 


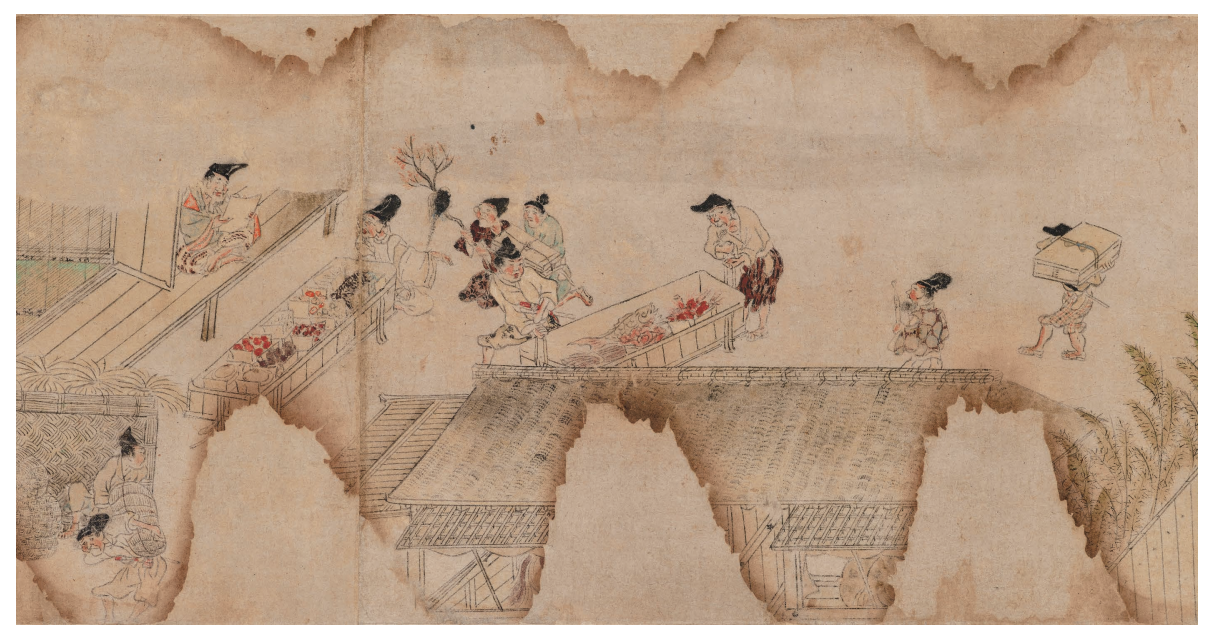

Figure 2. Treasures being carried into the rich man's mansion. Illustrated Legends of Kokawa Temple, Section 3. Permission of Kokawa Temple.

bales of rice in large quantities, marked off by a wickerwork fence. On the mansion's veranda, there is also what appears to be a steward in the service of the rich man, checking through the inventory list of items being delivered. In the scene within the house that follows, the rich man is meeting with a young ascetic. To the left of this, beyond a single room set with a sugorok $u$ board, there runs a hallway leading to yet another room where the man's sick daughter lies. Here the young ascetic is depicted a second time, now offering prayers at the daughter's pillow-side.

Section 4 presents a scene where many valuable objects-in the words of the text shicchin manpo 0 七珍万宝 (Seven Rarities and Myriad Treasures)—are offered up to the young ascetic, through whose prayers the daughter has now been completely cured. With the door to the storehouse opened wide, gold dust and bolts of silk, pots and trunks and various other items are brought forth. Of these gifts, however, the ascetic accepts none, and leaving the mansion, takes with him only the wood-bladed short-sword (sagesaya 提䩗) and crimson-dyed pants offered to him by the daughter herself.

In both sections, the assortment of treasures depicted is an eminently natural motif for the setting, and serves primarily to express the sheer wealth of the rich man. Nonetheless, the amount of illustrated space these depictions occupy is extravagantly large for mere purposes of situational exposition. In such a context, it will be useful to recall how the accumulation of wealth, in the iconography of Heian- and Kamakura-era paintings, was in fact frequently cast in a negative light.

An example of this can be seen in the Illustrated [Tale of] Major Counselor Tomo (Ban dainagon emaki $i$ 伴大納言絵巻, Idemitsu Museum Archives), another illustrated 
scroll thought to have been produced in the orbit of Retired Emperor GoShirakawa. The work's central characters are Minamoto no Makoto 源信 and Tomo no Yoshio 伴善男, two figures connected with the Burning of the Ōtenmon Gate 応天門 incident: the former because he was indicted for the crime unjustly (though later pardoned), and the latter because he unjustly escaped being indicted, until his guilt in the arson was exposed, and he found himself banished to far-off Izu. The scroll contains depictions of these two men in their respective living quarters. While in Minamoto no Makoto's room the only object depicted is an ink-stone case, in Tomo no Yoshio's room there are detailed depictions of a truly great variety of items: the bed-pillow shared with his wife, a sword placed at the pillow's head, a mirror case, a comb, a container of hair-styling liquid (yusuru-tsuki 泔坏), dishes on a painted tray, a pedestal tray bearing sake vessels and food. Both in the number and kind of their accoutrements, there is a clear, deliberate difference in the way the rooms of the innocent Minamoto no Makoto and the guilty Tomo no Yoshio are depicted, demonstrating that such accoutrements have a role beyond situational explanation alone. In particular, the sake vessels in Tomo no Yoshio's room are in conflict with one of the Five Precepts already discussed — that against drinking — and signal moreover the Buddhist character of the concept of sin here in operation.

A related iconography can be found in the motif of Niga-byakudō zu二河白道図, or "White Path Between Two Rivers" paintings, of which ten or more examples survive from the Kamakura and Muromachi periods. Niga-byakudō $q u$, which were used in all sects of Pure-Land Buddhism, were paintings in hanging-scroll format based on the "parable of the white path between the two rivers," as presented in the Kanmu ryōju kyōsho 観無量寿経疏, a scriptural commentary by Zendō 善導, an early Tang-dynasty systematizer of Pure-Land Buddhist teachings. Here I will consider the pictorial contents of such paintings, using a $13^{\text {th }}$-century example of the genre from the collection of Kōsetsu Museum 香雪美術館 (http: //bunka.nii.ac.jp/heritages/heritagebig/127087/0/1).

The lower portion of such paintings portrays the present world, overflowing in all its suffering and filth, while the upper part portrays the paradise of the Pure Land. Between lower and upper lie two rivers, one of fire and one of water, as well as a single white road straddling them both. The river of fire symbolizes wrath, while the river of water symbolizes desire. The white road in the center between the two symbolizes the wish for rebirth in the Pure Land as the only way to cast the worldly passions of wrath and desire aside, and attain entry thereby into the world of Amida Buddha.

Within the river of fire, there are depictions of people whose anger moves them to fight with others, or even to kill them. Meanwhile, in the river of water there are depictions of men and women and children, and surrounding them all sorts of treasures like bolts of silk, large baskets, bales of rice, swords, and gold dust, among many other things. The motifs drawn in the river of water here mirror those seen in Tomo no Yoshio's house in the Illustrated [Tale of] Major Counselor 
Tomo, and bear a resemblance in structure to the various items depicted in Sections 3 and 4 of the Illustrated Legends of Kokawa Temple.

In the Kanmu ryōju kyōsho commentary, the direct source for the Niga-byakudo zu paintings, there is no discussion of these rivers of fire and water in their concrete details. As Kasuya Makoto 加須屋誠 has already shown, however, there is a sutra that delineates in detail how wrath leads to fighting between people, and how desire encourages likewise an attachment to one's family and possessions: the Bussetsu muryōju kyo 仏説無量寿経. In analyzing the iconography of such paintings, the following passage from this sutra is helpful:

Beguiled by obsession and desire one falls short of the virtue of the right path, wallowing instead in wrath, consumed by the greed of treasure. On this account one fails to achieve the Way. Without exception one reverts to the wretchedness of the evil realms, fated for endless repetition of the cycle of life and death. How tragic! How truly grievous! Within the family, for a short spell, father and son, older and younger brother, husband and wife-though the one dies and the other lives they bear feelings for one another, cherishing and loving, lamenting and worrying even as it entraps them, longing for one another even as they wound each other's hearts. ${ }^{10}$

Religious thinking of this kind that inveighs against attachments to possessions and family can also be found in sutras like the Daihöshaku kyō 大宝積経 or the Daibō daishü kyō 大方大集経, both of which are quoted in the anthological $\bar{O} j \overline{0} y \bar{o} s h \bar{u}$ 往生要集. The following from the Ojjo yosh $\bar{u}$ is one such passage where the Daiböshaku kyō is quoted: ${ }^{11}$

In a verse passage of the Hōshaku kyō宝積経 it says: Though the treasure you acquired by so many evil deeds be a fund turned to the protection and happiness of your own wife and child, when at length you face life's end, from the suffering that then wracks your body no one, not even the same wife and child, has the power to save you. In the midst of your fear as you cross the ThreeFord River, you can rely neither upon wife and child nor upon any other family. Though cart and horse, wealth and treasure all pass on to others, who can share with you the suffering you then feel? Your father, mother, older brother and younger, wife and child; your friends and servants, your prized treasures; at the departure of death not a single one of them can offer you fellowship on the journey. Only your black deeds follow you ever to the last. ${ }^{12}$

Here it is repeatedly emphasized how any wealth accumulated by immoral or illegal means, even if used to then support one's own wife and child, is of no benefit when facing the hour of one's death, and indeed only produces negative karma. The words "cart and horse" can also be seen here alongside the other

\footnotetext{
${ }^{10}$ Taishō shinshü daizōoyyō 大正新脩大蔵経, vol. 12, p. $275 \mathrm{a}$.

${ }^{11}$ See the passage “Sōjite ensō wo musubu” 惣じて厭相を結ぶ in section 7 of Part 1: “Onri edo" 厭離欌土 [Spurning the Polluted World].

${ }^{12}$ Taishō shinshü daizōekyō 大正新修大蔵経, vol. 84, p. 39c.
} 
treasures. This is consistent with the Illustrated Legends of Kokawa Temple, where inside the rich man's mansion we indeed find depiction of a stable.

To judge by the above, it seems that the understanding of wealth as something not only valueless and unworthy of attachment-but indeed as something far worse, a possible source of karmic consequences — had already taken deep root alongside the spread of Pure Land Buddhism itself.

If in this fashion we work from the assumption of such a Buddhist contextparticularly of the Pure-Land variety - then taking the illness of the rich man's daughter as depicted in the Illustrated Legends of Kokawa Temple to be but the karmic result of her father's excess wealth, will seem an entirely natural interpretation. This can also be seen in the fact that in the succeeding Section 5, having followed the young ascetic all the way to Kokawa in longing, upon discovering him to have been an incarnation of Senju Kannon, the daughter is not the only one to then take vows immediately before that Kannon's statue. The narrative text makes it clear that vows were then taken by multiple people, with the phrase "Every one of them [in the end] left the world behind." Likewise the illustration, though centered on the daughter as she cuts her hair before the image of Kannon, shows not only her mother and father, but also other family members doing the same.

In the scene with which the second episode of the scroll concludes, where the entire family takes Buddhist vows, it is not the daughter's recovery from illness per se that has brought them to this true salvation. It was her recovery, however, that prompted her rich father to open up his storehouse, and to offer the young ascetic all the wealth accumulated there. It is thus in the entire household's abandonment of attachments to excess wealth, and in their desire to take vows and leave the world behind-guided by the merits of Senju Kannon-that the true concern of this illustrated temple legend scroll lies. Or to advance a somewhat sharper take, using the form of such a legend, this illustrated scroll is arguing for the dogmatic legitimacy of ridding oneself of excess wealth by donating it to religious establishments.

\section{The Merits of the Senju Dhärañī千手陀羅尼}

But let us here consider again the daughter's illness. Though for three years since her falling sick no prayer of any sort had had the slightest effect, with the young ascetic chanting the Senju dhäranī 手陀羅尼, by the morning of the seventh day the daughter's illness had been completely cured. The process by which this recovery was effected is recorded as follows in the narrative text of Sections 3 and 4. It begins thus in Section 3: "Here the you[th], sitting at her pillow-side, prays the [entire] Senju dharra[ni] without ceasing." Continuing this in Section 4 we have: "As he prayed, the pus [and blood drained out, while the pai]n gradually ceased. By early in the morning on the seventh day the girl was sitting up, feeling herself full of life [as before].” 
The Senju dhärani chanted here by the young ascetic is an incantatory prayer found in the Senju sengen Kanze'on bosatsu kōdai enman muge daibishin darani kyō 千手 千眼観世音菩薩広大円満無礙大悲心陀羅尼経, or Senju kyō千手経, a Chinese sutra translation made in the mid- $7^{\text {th }}$ century by Bhagavaddharma (J. Kabon Daruma 伽梵達磨). Indeed, the explication of this dhäranı 's effective power was the Senju ky $\vec{o}$ s very purpose as a sutra. Possessed of every sort of merit, the Senju dhärani was performed to secure a wide range of ends, from peace and prosperity at the national level to the fulfillment of individual petitions. Believed in particular to hold an unparalleled power for curing sickness, the Senju dhärañ makes frequent appearance as healing agent in accounts of illness recovery from Buddhist story collections of the Tang and Song eras. By the $8^{\text {th }}$ century the sutra had been brought to Japan, where as it proliferated in manuscript across the ancient and medieval periods, it left behind a rich record of literary adaptation: in waka poetry and in Buddhist tales, but also in various temple and shrine legends.

The contents of the Senju kyō and the Illustrated Legends of Kokawa Temple display several noteworthy points of convergence. First, the Senju kyō explains that when chanting the Senju dhärani, it is necessary to construct a purified space marked off on all four sides by a barrier drawn in one of the following ways:

Take up a sword, and after chanting (i.e. the dhäranì) 21 times, draw a line on the ground to mark out a barrier. Or take up purified water, and after chanting 21 times, sprinkle this on all four sides to mark out a barrier. Or take up white mustard seeds, and after chanting 21 times, strew these on all four sides to mark out a barrier. Or mark out a barrier at someplace that comes to mind. Or take up purified ashes, and after chanting 21 times, use these to mark out a barrier. Or take up a length of five-colored thread, and after chanting 21 times, wind it around all four sides to mark out a barrier. Any of these is sufficient. ${ }^{13}$

In the Illustrated Legends of Kokawa Temple, this practice of marking out a barrier on all four sides finds expression in the hermitage the hunter constructs prior to the appearance of the Senju Kannon statue. Called a "square-shaped hermitage room" in the narrative text of Section 2, it is made clear that this room is one divided off on all four sides, and by depicting such a hermitage in the illustrations repeatedly, the scroll impresses upon its viewers the image of a space purified for the appearance of Kannon's statue.

Secondly, as seen in the sutra passage here quoted, for the marking out of a barrier, any of the following methods might be employed: swords, purified water, white mustard seeds, thought, purified ashes, or a five-colored thread. Examining this scroll, in the illustration from Section 2 showing the Kannon statue's appearance, we find depicted inside the same hermitage two buckets of cypress wood with a ladle in each, a heating tripod bearing a kettle, and a stack of firewood. In addition, we can see outside the hermitage three bound bundles of plant leaves. Gorai Shigeru has pointed out that one might detect in such motifs a

${ }^{13}$ Taishō shinshü dairōkeyō 大正新脩大蔵経, vol. 20, p. 109b. 
kettle for conducting the yudate 湯立 (water-boiling) divination ceremony, together with bundles of cedar leaves (sugi 杉) or bamboo grass (sasa 笹) prepared for use in the same. Gorai has also raised the possibility of a connection with the incantations and oracles of mountain ascetics, but though the yudate ceremony was in its origins a form of divination, it was also employed for purposes of purification and exorcism. In this scene, such motifs should be understood as intended to signal that the hermitage in which the Kannon statue would appear was a space purified, and marked off by a set border, through the use of purified water.

A third point: in the Senju kyo there is the following passage explaining the proper method for chanting the Senju dhärani itself, after a border has been marked out as detailed above:

When perchance in some country disaster has befallen, should the king of that country be one who govern his land rightly, treating everything and everyone generously, and never abuse the populace, pardoning their trespasses always; if being such a king he will ritually purify himself in body and spirit for seven days and seven nights, chanting aloud this divine incantation of the dharani of the Great Merciful Heart, then shall that land be spared disaster entirely, and its crops see a bountiful harvest, and its people know peace and security. ${ }^{14}$

This explains how in order to attain the merits of the Senju dhärani, one must chant it aloud for seven days and seven nights. Indeed, even outside this quote, the same message is stressed elsewhere in the sutra repeatedly: that by chanting aloud the Senju dhärani for seven days and seven nights, one can attain its boundless merits in any matter.

Moreover, in the Illustrated Legends of Kokawa Temple too, a period of precisely seven days is invested with special significance, being mentioned in the scroll's narrative portion multiple times. The first of these is in the text of Section 2, after the young ascetic's self-seclusion in a hermitage: "After 7 days, when I went again to that same place and looked about, nothing had changed at all, and nothing had been opened. But when I opened it myself, [standing there] within, gleaming, wa[s] a life-sized statue of Senju Kannon." Here it is recorded that the appearance of the Senju Kannon statue occurred after his self-confinement of 7 days. There are further such occasions in the scroll's second episode, first of all in the narrative portion of Section 3, where the young ascetic has appeared in the rich man's house, and says: "If that is the case, I will try praying for seven days," thereby suggesting a seven-day period of prayer. Then in the narrative text of Section 4, as promised: "By early in the morning on the seventh day the girl was sitting up, finding herself full of life [as before]." Thus it is that the daughter's illness is cured on the morning of the seventh day.

As we have seen above, the manner in which the merits of Senju Kannon appear in the Illustrated Legends of Kokawa Temple clearly draws upon the teachings of the

${ }^{14}$ Taishō shinshū dairōkeyō 大正新脩大蔵経, vol. 20, p. 109c. 
Senju kyō千手経. Indeed, for practices like boundary-marking and the performance of seven-day prayers, a detailed understanding of actual Senju dhärani rituals is presumed. The scroll's attitude of devotion towards this sutra is in fact so earnest throughout, that one almost feels it attempting to make manifest-on the site of Kokawa-the world that the Senju kyo represents.

\section{Conclusion}

Recently, near Seventh Avenue there is a woman who lends money. The prosperity of her household, and the abundancy of her foodstores, have led her to such obesity that the very ampleness of her flesh now makes it difficult to walk. Her maidservants try to help her, but with all her sweating and shortness of breath, there is nothing to end her suffering.

This is the narrative text accompanying the section "An Obese Woman" in the illustrated scroll Yamai no soshi. ${ }^{15}$ A collection of portrayals of people suffering from various illnesses and deformities, this Yamai no sōshi is yet another work believed to have been produced in the orbit of Retired Emperor Go-Shirakawa. It also provides, in this passage above, an additional source for understanding the complex feelings its contemporary viewers had about the accumulation of wealth.

The woman depicted, a money-lender in the area of Seventh Avenue, has become so morbidly obese on all her wealth and food that she can no longer even really walk without assistance. Unlike with the stories in the Illustrated Legends of Kokawa Temple, however, for her there is no divine salvation forthcoming. This points to a great difference between the two scrolls in their attitudes towards illness.

In the Illustrated Legends of Kokawa Temple, people living with the burden of karmic sin are able, with the salvation offered by Senju Kannon in his limitless mercy, to once again be reincorporated into the order of religion. By contrast, in the case of the "obese woman," the reason for her illness is understood through a logic of causality wholly internal to the secular realm. The coolly critical eye cast upon her is thus merely the justified consequence of the obese woman's choice of moneylending as her life's profession.

The structural difference here between tales of illness and wealth as manifested in these two illustrated scrolls, as well as the sheer gap between their respective views on the sick, both indicate a certain fluctuation in the distance between the divine and the human. It is a fluctuation found also in the values of the works' assumed common patron, Retired Emperor Go-Shirakawa, and even in the value system of society itself, shifting as it was then from an Ancient world to a Medieval one.

Indeed, the two scrolls' different depictions of illness throw into sharp relief the two-sided nature of Go-Shirakawa's style of cloistered rule: for even as he

\footnotetext{
${ }^{15}$ In the collections of the Fukuoka Art Museum 福岡市美術館.
} 
trusted to the Buddhist Law through so many outbreaks of disease, war, and natural disaster, he also sought to overcome such problems by allying himself with the powers of this world — the newly ascendant warrior class very much included.

\section{References}

Gorai Shigeru 五来重. Emakimono to min₹oku 絵巻物と民俗. Tokyo: Kadokawa Shoten, 1981.

Kameda Tsutomu 亀田孜. “Kokawa-dera engi emaki sōkō” 粉河寺縁起絵巻綜考. Yamato bunka 大和文華 27, September 1958.

Kasuya Makoto 加須屋誠. “Niga-byakudō qu shiron: sono kyōriteki haikei to zuyō kōsei no mondai” 二河白道図試論：その教理的背景と図様構成の問題. Bijutsushi 美術史 127, February 1990. Also in Bukkyō setsunvaga no kō̃ō to kinō 仏教 説話画の構造と機能. Tokyo: Chūō Kōron Bijutsu Shuppan, 2003.

Kasuya Makoto 加須屋誠 and Yamamoto Satomi 山本聡美, eds. Yamai no sōshi 病草紙. Tokyo: Chūō Kōron Bijutsu Shuppan, 2017.

Matsubara Shigeru 松原茂. “Kokawa-dera engi no kotobagaki shofū ni tsuite” 「粉河寺縁起」の詞書書風について, in vol. 5 of Nibon emaki taisei 日本絵巻 大成. Tokyo: Chūō Kōronsha, 1977.

Ōgushi Sumio 大串純夫. “Kokawa-dera engi bubun: zuhan yōryō” 粉河寺縁起 部分：図版要領. Bijutsu kenkyu 美術研究 171, November 1953.

Shimizu Yoshiaki 清水義明. “Kokawa-dera engi fukugen e no ichi-kōsatsu”「粉河寺 縁起」復元への一考察. Bukkeyō geijutsu 仏教芸術 86, July 1972.

Umezu Jirō 梅津次郎. “Kokawa-dera engi-e to Kibi daijin nittō-e” 粉河寺縁起絵と吉 備大臣入唐絵, in vol. 5 of Nibon emaki-mono zenshū 日本絵巻物全集. Tokyo: Kadokawa Shoten, 1962. 